\title{
ADAM SMITH, NATURAL EXTRACTION AND HISTORICAL JUDGEMENT: AN UNWARRANTED ENVIRONMENTAL LEGACY'
}

JAMES CULLIS

University of Oxford

\section{Abstract}

Within the field of environmental history, assumptions about the development of political and economic ideas have tended to overlook the complex intellectual and historical context that gave rise to them. This article argues that this has certainly been the case in interpretations of Adam Smith by environmental historians. Through drawing on scholarship in intellectual history, this short essay reveals how Smith's evaluation of natural extraction was directly linked to his conception of political economy. In the process, it also demonstrates a need for environmental historians to reassess Smith's environmental legacy.

Keywords: Adam Smith, environmental historiography, environmental history, capitalism, Enlightenment

Adam Smith's presumed legacy regarding the issue of environmental regulation is controversial to say the least. Unfettered free-market exploitation of natural resources has tended to be the dominant narrative with which we understand his contribution to environmental debates, especially mining. ${ }^{2}$ Smith's attitude towards the subject was in part motivated by a rising discussion over natural resources, especially coal consumption. Although aware of these mining debates, Smith appears to have registered minimal, if any, interest in the economic potential associated with the subject. ${ }^{3}$ Yet mining did play a considerable part in how he understood the history of political economy. In both the Wealth of Nations and Lectures on Jurisprudence,

\footnotetext{
1 This paper emerged out of a presentation given at the World Congress of Environmental History, 22-26 July 2019, Federal University of Santa Catarina (Universidade Federal de Santa Catarina, UFSC), Florianópolis, Brazil, entitled 'The Extravagance of Minerals: Adam Smith on the Pitfalls of Natural Extraction'. My thanks to Gerrado Serra, James Beattie and anonymous readers for their comments.

2 For an example of how Smith is used in contemporary debates over mining and development, see Omar Zambrano, Marcos Robles and Denisse Laos, Global Boom, Local Impacts: Mining Revenues and Subnational Outcomes in Peru 2007-2011, No. IDB-WP-509, IDB Working Paper Series, 2014, 2.

3 Fredrik Jonsson, Enlightenment's Frontier: The Scottish Highlands and the Origins of Enviromentalism (New Haven, CT: Yale University Press, 2013), 174.
} 
Smith would develop a critique of mining that rejected the commercial value of the natural resources found underground, in favour of the productive capacity of pastoral lands. Through taking Smith's writings on natural extraction seriously, there is an urgent need for the discipline of environmental history to reassess and contextualise his argument in Enlightenment debates over resource management and political economy. Since the 1970s, intellectual historians have demonstrated that Smith's work cannot be completely aligned with the underlying theory of a capitalist economy. ${ }^{4}$ As Reinhard Schumacher notes, modern economic interpretations of his corpus have skewed the nature of his ideas in order to fit a precise historical narrative. ${ }^{5}$ Here, work done by intellectual historians such as Quentin Skinner is crucial to discovering why Smith has been so misread. Through drawing on this body of scholarship, this short essay will reveal how Smith's evaluation of natural extraction was directly linked to his conception of political economy. In the process, it will also demonstrate a need for environmental historians to reassess Smith's environmental legacy.

Within the field of environmental history, assumptions about the development of political and economic ideas have tended to overlook the complex intellectual and historical context that gave rise to them. For Skinner, the sole focus on close reading without any reference to the social or historical context of a text's production obscures a full understanding of its significance. ${ }^{6}$ Central to this is the rejection of the notion that any historical corpus of work seeks to contribute to certain perennial philosophical questions. As an approach to the history of ideas, Skinner's argument is crucial to any analyses of Smith's attitude towards mining. A significant concern raised by Skinner is how historical arguments are often understood through a form of prolepsis - that is, reading a historical text as if it contained the seeds of future ideas, or that the author intended the text to be understood in a particular way by subsequent generations. ${ }^{7}$ Exploring the intellectual character of Smith's work in this light has consequences for environmental history because of the way it refocuses attention away from the perceived modern consequences of his ideas onto an examination of his original aims in writing them.

4 See, for example, Istvan Hont, Jealousy of Trade: International Competition and the Nation-State in Historical Perspective (Cambridge, MA: Harvard University Press, 2005); Istvan Hont, Politics in Commercial Society: Jean-Jacques Rousseau and Adam Smith, ed. Béla Kapossy and Michael Sonenscher (Cambridge, MA: Harvard University Press, 2015); Ronald Meek, Social Science and the Ignoble Savage (Cambridge: Cambridge University Press, 1976); Nicholas Phillipson, Adam Smith: An Enlightened Life (London: Penguin, 2011); Donald Winch, Adam Smith's Politics: An Essay in Historiographic Revision (Cambridge: Cambridge University Press, 1978); Donald Winch, 'Adam Smith's "Enduring Particular Result": A Political and Cosmopolitan Perspective', in Wealth \& Virtue: The Shaping of Political Economy in the Scottish Enlightenment, ed. Michael Ignatieff and Istvan Hont (Cambridge: Cambridge University Press, 1983).

5 Reinhard Schumacher, 'Adam Smith's Theory of Absolute Advantage and the Use of Doxography in the History of Economics', Erasmus Journal for Philosophy and Economics 5, no. 2 (2012): 54-80.

6 Quentin Skinner, 'Meaning and Understanding in the History of Ideas', History and Theory 8, no. 1 (1969): 3-53.

7 Skinner, 'Meaning and Understanding', 24. 
For some commentators, Smith's lack of concern with the issue reflected a general eighteenth-century lack of interest in questions relating to the natural world. ${ }^{8}$ Others, notably Donald Worster, whilst recognising that Smith did consider environmental questions, argue that this was only because it was instrumental to his overall economic project. ${ }^{9}$ Such interpretations neatly parallel a particular understanding of his place in the history of economic thought that stress a linear historical development of economic ideas. ${ }^{10}$ Seen in this light, understandings of Smith's ideas conform to a Whig historical narrative in which economic history is aligned with political liberalism. ${ }^{11}$ This point is crucial in terms of providing an indication of how his commentary on environmental issues has been marginalised through an overemphasis on his economic writings coupled with a particular view of his place within the broader Enlightenment project of 'Modernity'. Through placing his attitude to mining within the context of his historical writings, this short essay allows for an exploration of the nuances and complexity of his environmental ideas.

In the latter half of the eighteenth century, political debate in Britain was shaped to a degree by the question of industrialisation. ${ }^{12}$ As Willian Cavert notes, fossil fuel pollution was a significant concern for the citizens of urban centres such as London. ${ }^{13}$ Between 1763 and 1834, the issue of coal consumption, and by extension natural resource extraction, took a hold of domestic concerns and shaped the political agenda and wider social discourse. ${ }^{14}$ For Smith, mining played a considerable part in how he understood the history of political economy. According to some mid-twentieth-century commentators, notably Friedrich Hayek, Smith's economic arguments centred on the social benefits of individual choice. ${ }^{15}$ Yet Smith's attitude towards mining, as revealed in his writing, reveals a scepticism with regard to the profitability and necessity of such action. Understood within the context of his wider account of historical progress, Smith's arguments predominately focused on the consequences of mining on particular colonial projects. Through addressing the

8 Agnar Sandmo, 'The Early History of Environmental Economics', Review of Environmental Economics and Policy 9, no. 1 (2015): 46.

9 Donald Worster, The Wealth of Nature: Environmental History and the Ecological Imagination (New York: Oxford University Press, 1993), 214-16.

10 Schumacher, 'Adam Smith's Theory of Absolute Advantage', 68.

11 Paul Samuelson, 'Out of the Closet: A Program For the Whig History of Economic Science: Keynote Address at History of Economics Society Boston Meeting, June 20, 1987', Journal of the History of Economic Thought 9, no. 1 (1987): 51-60.

12 Michael Flinn and David Stoker, The History of the British Coal Industry, vol. II (Oxford: Clarendon Press, 1984), 449-57.

13 William Cavert, The Smoke of London: Energy and Environment in the Early Modern City (Cambridge: Cambridge University Press, 2016).

14 ibid., xiv-xv.

15 Friedrich Hayek, Studies in Philosophy, Politics and Economics (Chicago: University of Chicago Press, 1967), 99, cited in Alan Ebenstein, Friedrich Hayek: A Biography (Chicago: University of Chicago Press, 2003), 250. 
issue in these terms, Smith would go on to develop a critique of mercantilism, which was characterised by a rejection of the economic value of the natural resources found under the ground, in favour of the productive capacity of the topsoil.

In Book Four of the Wealth of Nations, Smith raises the problem of mining in relation to the European colonial project. In Chapter Six, he examines the motivations for the European 'discovery' of America—and in particular Spain's quest for gold. For him, the Spanish drive to extract minerals brought with it both a degree of uncertainty and the absorption of capital:

It is perhaps the most disadvantageous lottery in the world, or the one in which the gain of those who draw the prizes bears the least proportion to the loss of those who draw the blanks: for though the prizes are few and the blanks many, the common price of a ticket is the whole fortune of a very rich man. Projects of mining, instead of replacing the capital employed in them, together with the ordinary profits of stock, commonly absorb both capital and profit. ${ }^{16}$

Whilst many Enlightenment commentators understood the episode as the consequence of the rise of luxury with the advent of commercial society, for Smith, alongside David Hume, the decline of the Spanish Empire was the result of a flawed overvaluing of bullion and the national accumulation of precious metal. ${ }^{17}$ Part of these concerns were to do with the cost-effectiveness of the mining process. As Smith notes in the Lectures on Jurisprudence:

A man who cultivates one acre, by cultivating two or a certain method of treating that one, can be almost certain of doubling his stock of corn; but he has no such certainty that by applying double industry to the mine he shall multiply in the same proportion the quantity of gold and silver. ${ }^{18}$

Through reasoning that the benefits of natural extraction were limited, Smith alluded to a significant point about his conception of the environment-namely, that financial and practical constraints arise when seeking to exploit the resources beneath the earth's surface. These concerns centred on the belief that the pursuit of such activity was futile as the amount of geographic space where the metal was thought to be present was limited. ${ }^{19}$ This sceptical view must ultimately force environmental historians to ask why they continue to permit Smith's ideas to be used to justify deregulation and so-called 'economic progress' at the expense of environmental degradation.

16 Adam Smith, An Inquiry into the Nature and Causes of the Wealth of Nations, vol. I, ed. R. H. Campbell, A. S. Skinner and W. B. Todd (Indianapolis, IN: Liberty Fund, 1976), 562.

17 Fredrick Whelan, 'Eighteenth Century Scottish Political Economy and the Decline of Imperial Spain', Journal of Scottish Historical Studies 38, no. 1 (2018): 59-61.

18 Adam Smith, Lectures on Jurisprudence, ed. R. L. Meek, D. D. Raphael and P. G. Stein (Indianapolis, IN: Liberty Fund, 1982), 345.

19 Smith, Lectures on Jurisprudence, 507-8. 
Smith's understanding of natural extraction came out of an overarching account of societal progress. It was within this context that he revealed a cautious attitude towards the subject, driven primarily by the idea that such activity used up time and economic resources. As a substitute, Smith emphasised how European history was shaped to a large degree by the link between the urban and rural landscapes. This point is significant as it demonstrates how he saw mining to be superfluous to the needs of the modern commercial economy. In Book Three of the Wealth of Nations, Smith provided an account of the way in which agricultural production was stimulated by the growth of towns and cities. Here, the idea of an 'unnatural and retrograde order' took agriculture to play a significant part in the emergence of the new social environments. ${ }^{20}$ In this sense, Smith's commentary on mining marked a shift in the understanding of the foundations of economic success from those based on mineral accumulation, to those driven by cultivation and land-use. Whilst historians have noted the importance of Smith's preference for the economic potential of agricultural production, they have overlooked the consequences this had on his judgement of the historical record of certain societies. ${ }^{21}$ Thus natural extraction was linked to the 'jealousy of trade' and the Renaissance doctrine of republican grandeur. ${ }^{22}$ It is this sense of the failed notion of competition between rival nation-states, and by extension empires, that encapsulates his critique of Spain. In the Lectures, Smith highlighted his concerns over the economic sustainability of mining through noting the effects of ownership on Spain and Portugal's domestic economies:

When they got possession of the mines of Mexico and Peru, they thought they could command all Europe by the continual supplies which they received from thence, if they could keep the money among them, and therefore they prohibited the exportation of it. But this had a quite contrary effect, for when money is, as it were, dammed up to an unnatural height, and there is more than the circulation requires, the consequences are very unfavourable to the country. ${ }^{23}$

By revealing the resulting negative influence it had on their currencies, Smith drew attention to the financial cost to both states' economies. Drawing on this insight allows environmental historians to rethink the way they characterise Smith's legacy on questions of resource extraction and state investment. By reconstructing the historical context in which he wrote, this essay has revealed the need to take into consideration this point when assessing his contribution to the broader historical environmental debate. Thus Smith's attitude to mining comes out of his own prior intellectual commitments: one that was not wholly dominated by an impending

\footnotetext{
20 Smith, Wealth of Nations, 409.

21 Edward Wrigley, 'The Transition to an Advanced Organic Economy: Half a Millennium of English Agriculture', Economic History Review 59, no. 3 (2006): 477.

22 Hont, Jealousy of Trade, 1-2. The idea of a 'jealousy of trade' comes from David Hume's essay of the same name, which in turn was taken from Thomas Hobbes' discussion of human nature in Chapter 13 of Leviathan: see David Hume, Political Essays, ed. Knud Haakonssen (Cambridge: Cambridge University Press, 1994), 150-1.

23 Smith, Lectures on Jurisprudence, 564.
} 
revolution in economic thought, but by a detailed reconstruction of the past. Instead of reading Smith as part of a grand narrative, with a view to explaining the current ecological crises with reference to his presumed legacy, the discipline of environmental history ought to recognise both the historical context in which an argument was made and the authors' immediate intentions. Understood in these terms, Smith's commentary on mining reveals very intimately the way discussions of certain authors have neglected the precise historical context in which they wrote. It is therefore crucial that environmental history pays a certain amount of attention to this aspect in order to fully recover a more comprehensive picture of how certain historical ideas have been adopted to justify particular contemporary actions.

\section{Conclusion}

Through understanding Smith's comments on mining as part of his overarching historical analyses of the failure of mercantilism, this essay has demonstrated that emphasis must be placed on the intellectual context in which he wrote and not the meaning ascribed to his ideas today. In this regard, the type of political economy advocated by him looked to a shift in thinking away from the mercantile logic of the past, towards the advent of commercial society. Thus through his examination of the fall of the Spanish Empire, Smith was able to show how the desire for gold and silver undermined the needs of the development of a modern commercial economic structure. It was the condition of the land and not the minerals beneath it that contributed to a society's development. On this reading, natural extraction was contrasted with agricultural production and its relationship with the development of an urban economy. At the root of Smith's conception of the retrograde order was a view of European history in which agricultural improvement was spurred on by developments in the urban setting. Thus the local rural farmlands became the suppliers on which large towns could draw. Within the present context, Smith's point undercut any estimation of the importance of mining through redirecting the focus away from mineral extraction, on to how investment in agricultural production and the cultivation of the soil aided the emergence of a commercial society. Rather than seeing him as initiating the doctrine of exploiting natural resources, environmental historians ought to reconsider the role of 'history' and 'ideas' when assessing Smith's contribution to debates surrounding the natural world.

Adam Smith's legacy is not one that should be rejected lightly. His contribution to historical and moral debates equalled if not exceeded those of his contemporaries. Questions over his legacy do raise legitimate concerns, particularly over the environment and its relationship to the market. Yet by revisiting his texts, environmental historians can demonstrate inaccuracies in portraying him as the forerunner of deregulation and neo-liberalism. Drawing on the work of scholars such as Skinner, they can also move the discipline towards accepting the problematic 
role played by historical intellectual contexts in informing environmental debate. Seeing Smith's commentary on mining in these terms allows historians to appreciate the nuances of his argument. Picking up on this point, environmental history can isolate and interrogate issues of legacy separately from the original texts themselves. Doing so will provide opportunities to better comprehend human understandings of the natural world. It might also stimulate a wider debate about the relationship between intellectual history and the environment. 
This text is taken from International Review of Environmental History, Volume 5, Issue 2, 2019, edited by James Beattie, published 2019 by ANU Press, The Australian National University, Canberra, Australia.

doi.org/10.22459/IREH.05.02.2019.05 